Yüzüncü Yil Üniversitesi
Tarim Bilimleri Dergisi

Araştırma Makalesi (Research Article)

\title{
Farklı Ekolojilerde Yetişen Fındık (Corylus avellana L.) Çeşit ve Genotiplerinin Stoma Yoğunluk ve Dağılımlarının Belirlenmesi
}

\author{
Haydar HURT ${ }^{* 1}$, Adnan DOĞAN ${ }^{2}$ \\ ${ }^{1,2}$ Yüzüncü Yıl Üniversitesi, Ziraat Fakültesi, Bahçe Bitkileri Bölümü, 65080, Van, Türkiye \\ ${ }^{1}$ https://orcid.org/0000-0002-4637-1996 ${ }^{2}$ https://orcid.org/0000-0002- 8623-0629 \\ *Sorumlu yazar e-posta: kurthaydar61@gmail.com
}

\section{Makale Bilgileri}

Geliş: 18.03.2020

Kabul: 07.08.2020

Online Yayınlanma 30.09.2020

DOI: $10.29133 /$ yyutbd.705671

\section{Anahtar kelimeler}

Find1k,

Stoma,

Stoma yoğunluğu,

Stoma indeksi
Öz: Bu çalışmada, iki farklı ekoloji olan Trabzon ve Hizan (Bitlis) ilçesinde yetiştirilen 11 findık çeşidi ve tipinin yapraklarındaki stoma sayıları ve dağılımı incelenmiştir. Stomalar, hipostomatik olarak sadece yaprak alt yüzeyinde gözlenmiștir. Stoma sayısı birim alanda $\left(\mathrm{mm}^{2}\right) 90.00$ (Turșink) ile 111.60 (Himdi) adet arasında değişim göstermiştir. Çeşitlerin stoma uzunluğu ve genişliği 23.31 (Herişte) - 32.03 (Foşa) ve 19.20 (Cavreş) - 26.78 (Foşa) aralığında belirlenmiştir. Stoma uzunluğu ve genişliği açısından üst değerler Foşa findık çeşidinde belirlenmiștir. Fındık çeşitleri ve türleri arasında Himdi en yüksek stoma indeksine (\%19.43) sahipken Cavreş en düşük stoma indeksine (\%13.26) sahiptir. Çeşit ve tiplerin yaprak epidermis hücrelerinin sayısı 462.82 ile 612.46 adet $/ \mathrm{mm}^{2}$ arasında değişim göstermiş̧tir. Stoma sayısı ile stoma uzunluğu (-0.684-0.358) ve stoma genişliği (-0.706-0.856) arasında negatif korelasyonlar bulunmuștur. Bu sonuçlar, findık çeşitlerinin ve genotiplerin farklı stoma özelliklerine sahip olduğunu göstermiştir. Findıklarda stoma yapılarının belirlenmesinde en iyi yöntemin saydamlaştırma yöntemi olduğu gözlemlenmiştir.

\section{Determination of Stoma Density and Distribution of Hazelnut (Corylus avellana L.) Cultivars and Genotypes Grown in Different Ecologies}

\section{Article Info}

Received: 18.03 .2020

Accepted: 07.08.2020

Online Published 30.09.2020

DOI: 10.29133 /yyutbd. 705671

\section{Keywords}

Hazelnut,

Stomata,

Stomata density,

Stomata index

\begin{abstract}
In this study, the numbers and distribution of stomata in the leaves of eleven hazelnut cultivars and types grown in Trabzon and Hizan (Bitlis) district, which are two different ecologies, were examined. Stomata were observed hypostomatically only on the lower leaf surface The number of stoma in unit area $\left(\mathrm{mm}^{2}\right)$ ranged from 90.00 (Turşink) to 111.60 (Himdi). The stoma length and stoma width of the cultivars were measured in the range of 23.31 (Herişte) -32.03 (Foşa) and 19.20 (Cavreş) - 26.78 (Foşa). The highest values in terms of stoma length and stoma width were determined in Foşa hazelnut variety. Among the hazelnut cultivars and types, Himdi had the highest stoma index $(19.43 \%)$, while Cavreş had the lowest stoma index (13.26\%). The number of epidermis cells in the leaves of the cultivars and types ranged from 462.82 to 612.46 stoma $\mathrm{mm}^{-2}$. Negative correlations were found between the number of stoma and stoma length (-0.684$0.358)$ and stoma width $(-0.706-0.856)$. These results showed the hazelnut varieties and genotypes have different stomata characteristics. It has been observed that the best method for determining the stomata structures in hazelnuts is the method of transparency
\end{abstract}




\section{Giriş}

Stoma bitkinin toprak üstündeki organlarının hava alışverişini sağlayan epiderma hücreleri arasında oluşan bir yapıdır. Bitkilerin adapte olma kabiliyetleri yapraklarda meydana gelen transpirasyon ve fotosentez ile ilişkilidir. Stoma olarak adlandırılan küçük gözenekler ile atmosfer ile yaprak arasında su buharı, $\mathrm{CO}_{2}$, ve $\mathrm{O}_{2}$ alışverişini sağlayarak transpirasyon ve fotosentezin oluşumuna etki etmektedir. Su stresi stoma açıklıklarının küçülmesine ya da tamamen kapanmasına neden olarak gaz alışverişini sınırlandırmaktadır. Ayrıca, birim yaprak yüzeyindeki stoma sayısı gaz alışverişini etkilemektedir (Brownlee, 2001).

Stomalar türlere göre yaprağın her iki yüzeyinde (amfistomatik), sadece alt yüzeyinde (hipostomatik) ya da üst yüzeyinde (epistomatik) bulunabilmekte olup bir $\mathrm{mm}^{2}$ yaprak alanındaki stoma sayısı (stoma yoğunluğu) tür ve çeşitlere göre değişiklik arz etmektedir (Brownlee, 2001; Çağlar ve ark. 2004). Yaprakları tamamen güneşte bulunan bitkilerde stomalar yaprakların alt yüzeylerinde yer alırlar. Stomalar genel olarak epidermisle aynı yüzeyde bulunmaktadır. Stoma üzerine yapılan araştırmalarda, stoma sayısının kuraklığa dayanım (Şahin ve Soylu, 1991; Düzenli ve Ergenoğlu, 1991; Küçükyumruk ve ark., 2015), net fotosentez üretimi (Bierhuizen ve ark., 1984) ve vejetatif gelişme (Çağlar ve Tekin, 1999; Çağlar ve ark., 2004) gibi çeşitli özelliklerle bağlantılı olduğunu farklı araştırıcılar rapor etmektedirler.

Stoma sayısı ve anatomisi bitki türlerine, çeşitlere ve hatta klonlara göre değişebildiği bildirilmektedir (Çağlar ve ark., 2004; Sohie ve ark., 2008). Stoma bitki-su ilişkilerinin düzenlemesinde önemli role sahip olup su kaybının yaklaşık \%85-90'nı stomalardan gerçekleşmektedir (Yentür, 1984). Bu nedenle, stoma anatomisini, sayısını ve yapraklardaki yerini bilmek önemlidir. Stoma anatomisi ve sayısı; elmada, kestane, ceviz, üzüm, kiraz, mahlep ve incir üzerinde çalışmalar yapılmış olmasına rağmen fındıklarda yapılan çalışmalar çok azdır (Avcı ve Aygün, 2014). Stomaların fotosentez, fizyolojik süreçler, terleme, çevresel faktörlere tepkiler gibi süreçler üzerine önemli etkileri bulunmaktadır (Sarwar ve ark., 2013; Aras ve Eşitken, 2019).

Türkiye en büyük findık üreticisi ve gen merkezleri arasında bulunmaktadır. Ülke olarak Dünya findık üretim ve ticaretinin yaklaşık \% 70'ini karşılamaktayız. Türk findık çeşitleri benzersiz nitelik ve özellikleri nedeniyle ithalatçılar tarafından oldukça rağbet görmektedir. Türkiye orjinli findık çeşit ve tiplerinin stoma özellikleri üzerine çalı̧̧malara literatürde çok az rastlanılmıştır (Avcı ve Aygün, 2014). Bu araştırmada iki farklı ekolojilerde yetişen (Trabzon ve Bitlis-Hizan) fındık çeşit ve tiplerinin stoma yoğunlukları ve anatomisinin saptanması amaçlanmıştır.

\section{Materyal ve Yöntem}

$\mathrm{Bu}$ çalışma, Trabzon ilinde yetiştirilen Tombul, Foşa çeşitleri ve Giresun genotipi ile Hizan (Bitlis) ilçesinde yetiştirilen 8 farklı findık genotipi üzerinde 2019 yılında yürütülmüştür. Toplamda 11 fındık çeşit ve genotipi çalışma kapsamında yer almaktadır. Farklı iki ekolojiden alınan findıklar aynı bahçeden alınmış benzer yetiştirilme düzeylerine sahiptirler. Denemedeki fındıklardan Trabzon'dan seçilmiş olanlar Karadeniz iklimi etkisinde, Hizan (Bitlis)'ten seçilmiş olanlar ise karasal iklimin etkisindedir. Çalışmanın amacı; fındık çeşit ve genotiplerinin yapraklarında kalıp alma ve saydamlaştırma yöntemleri kullanılarak stoma yoğunlukları ve büyüklüklerini, epidermal hücre sayıları ile stoma indeksini belirlemek amaçlanmıştır.

Seçilen fındık çeşit ve genotiplerinde stoma sayım ve ölçümleri için findık ocaklarının 4 farklı yönünde bulunan dalların yıllık sürgünlerinin uç kısmından itibaren geriye doğru 3. ve 4. yaprakları kullanılmıştır. Yaprak temmuz ayının ikinci yarısında alınmış olup, gözlemler taze yapraklar üzerinde gerçekleştirilmiştir.

Yaprak örneklerinin ana damarları boyunca alt yüzeyinin sağından ve solundan $2 \mathrm{~cm}$ çapında özel bir zımba ile üç farklı kısımdan (dip orta uç kısımlardan) parça alınarak hazırlanan solüsyonun içine üzerine kurşun kalemle yazılabilen muşamba üzerine tel zımba ile zımbalanarak yerleştirilmiştir.

Saydamlaştırma yönteminde \%'lik sodyum hipokloritin içine konulan örnekler oda sicaklığında $\left(22-23{ }^{\circ} \mathrm{C}\right)$ 24-36 saat bekletilerek istenen düzeyde saydamlaşmanın olması sağlanmıştır (Durmaz, 2014). 

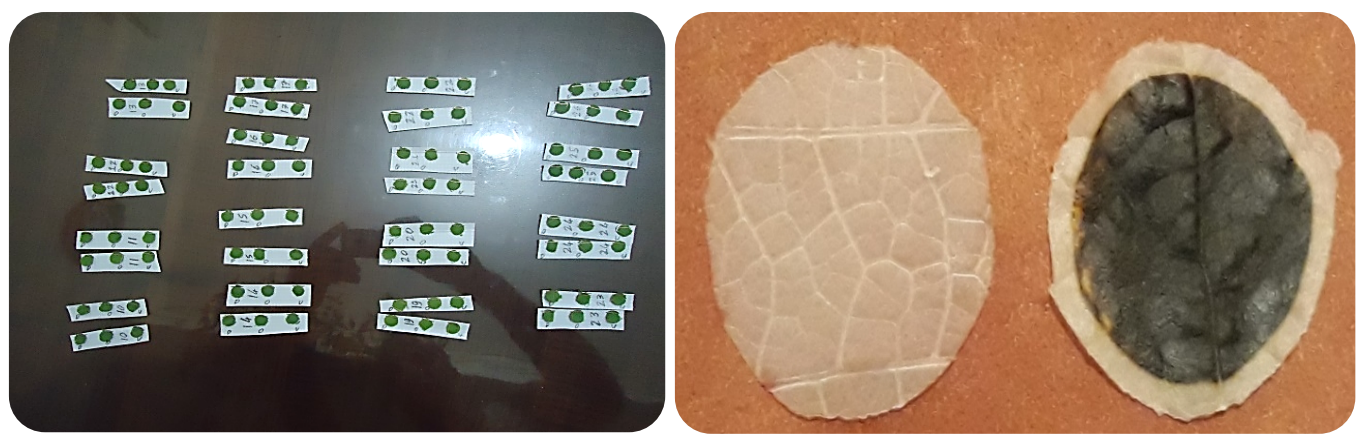

Şekil 1. Saydamlaştırma yöntemine ait fotoğraflar.

\section{Saydamlaştırma solüsyonu}

Yaprakların dip uç orta kısımlarından alınan örnekler saydamlaştırılmasında sodyum hipokloritin $(\mathrm{NaClO}) \% 5$ solüsyonu kullanılmıştır. Yapraklardan alınan parçalar solüsyon içerisine muşambaya tel zımba ile zımbalanarak tutturulmuştur. Oda sicaklığında $\left(22-23{ }^{\circ} \mathrm{C}\right) 24-36$ saat bu solüsyon içerisinde tutulan örnekler tamamen saydam hale geldikten sonra lam üzerine alınarak Mikroskopta 40x büyütmede kareli oküler mikrometrede kalıptaki stoma adedi belirlenmiştir (Eriş ve Soylu, 1992). Stoma sayıs1 ve birim alandaki epidermal hücreler $\left(1 \mathrm{~mm}^{2}\right)$ belirlendi ve stoma indeksi (SI) yüzde olarak aşağıdaki formüle göre hesaplanmıştır (Meidner ve Mainsfield, 1969).

$$
\text { Stoma indeksi }(\mathrm{SI})=\frac{\text { Birim alandaki stoma sayısı }}{\text { Birim alandaki stoma sayısı }+ \text { Birim alan başına epidermal hücre sayısı }} \times 100
$$

\section{Sodyum hipoklorit}

Bir tür tuz olan Sodyum hipoklorit $(\mathrm{NaClO})$ günlük hayatta çamaşır beyazlatıcı olarak kullanılmaktadır. Bu madde oda koşullarında sabunlardaki sodyum hidroksit ve klorun birleşmesi ile üretilmektedir. Sodyum hipoklorit formülü aşağıdaki gibidir:

$$
2 \mathrm{NaOH}+\mathrm{Cl}_{2} \rightarrow \mathrm{NaCl}+\mathrm{NaClO}+\mathrm{H}_{2} \mathrm{O}
$$

\section{İstatistiksel analizler}

Çalışma üç tekerrürlü olarak tesadüf parselleri deneme desenine göre kurulmuştur. Çalışma her bir çeşit veya genotipten dokuz örnek, toplamda ise 99 örnek üzerinde gerçekleştirilmiştir. Çalışmada Statgraphics istatistiksel paket programı kullanılmıştır. Veriler faktöriyel varyans analizine tabi tutulmuş olup gruplar arasında ki istatistiki farkı ortaya çıkarmak amacıyla LSD $(\mathrm{P}<0.05)$ testinden yararlanılmıştır.

Yapraklarda stoma dağılımları Tombul çeşidinin yaprağındaki stoma hücresi ve epidermal hücre yapıları Şekil 2. gösterilmiştir. Yöntem olarak kalıp alma yöntemi kullanılamadığından saydamlaştırma yönteminin tercih edilmesinin nedeni tüm findık çeşit ve tiplerinin yapraklarında Şekil 2'de görüleceği üzere yüksek tüylülük oranları, fındık yapraklarının gevrek (yırtılmaya yatkın) yapıda olması ve yaprak yüzey dalgalanmalarının çok fazla olması nedeni ile kalıp alma yönteminin kullanışlı olmadığına kanaat getirilmiş olup çalışmada saydamlaştırma metodu ile devam edilmiştir. 

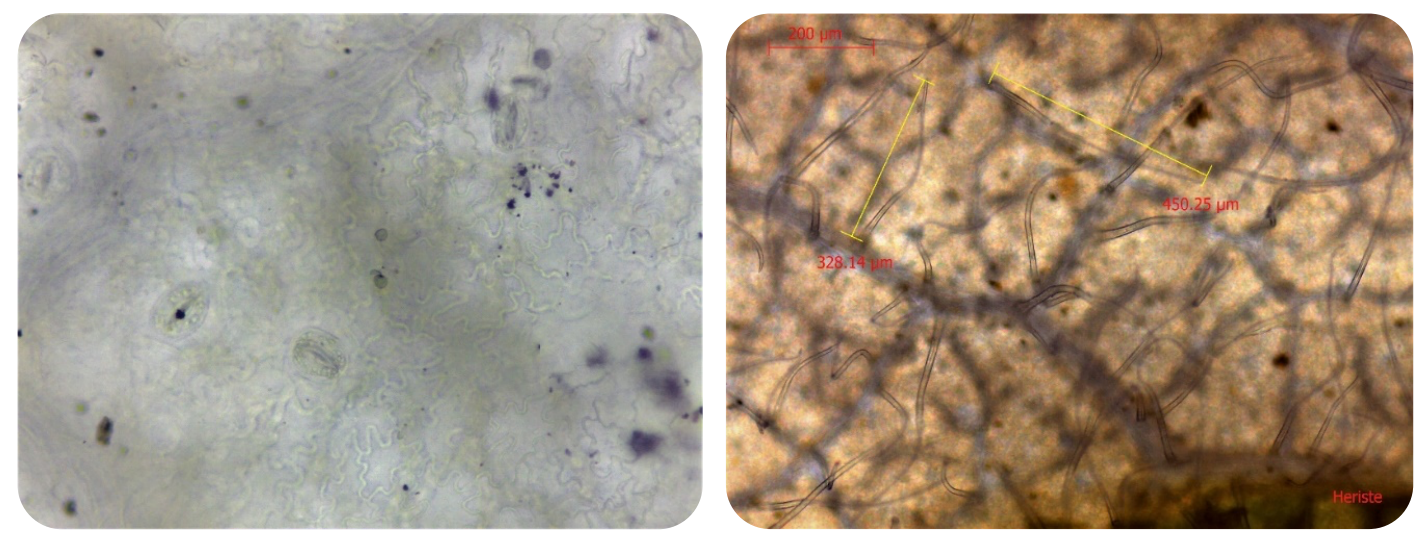

Şekil 2. Tombul fındık çeşidinin yapraklarındaki stoma ve epidermal hücrelerin ve yaprak tüylülügünün görünüşü.

\section{Bulgular ve Tartışma}

Yapılan araştırmada findık çeşit ve genotiplerinde yaprakların üst yüzeyinde stomaya rastlanmamıştır. Fındık yapraklarının sadece alt yüzeyinde stomalar tespit edilmiştir. Üzerinde çalışılan findık çeşit ve genotiplerinin hipostomatik olduğu belirlenmiştir.

Çizelge 1. Stoma yoğunlukları ve boyutlarına ilişkin varyans analiz sonuçları

\begin{tabular}{|c|c|c|c|c|}
\hline & \multicolumn{4}{|c|}{ Stoma yoğunluklarına iliskin varyans analizi } \\
\hline Varyasyon Kaynağ & S.D. & K.T. & K.O. & F-Değeri \\
\hline A: Çeşit-Genotip & 10 & 22805.8 & 2280.58 & $88.95 * * *$ \\
\hline B: Dip / Orta / Uç & 2 & 217.375 & 31.0535 & $1.21^{\text {ö.D. }}$ \\
\hline C: Tekerrür & 2 & 190.865 & 95.4327 & $4.20 *$ \\
\hline Hata & 84 & 1794.67 & 25.6381 & \\
\hline \multirow[t]{2}{*}{ Toplam } & 98 & 24817.8 & & \\
\hline & \multicolumn{4}{|c|}{ Stoma boylarına ilişkin varyans analizi } \\
\hline Varyasyon Kaynağ1 & S.D. & K.T. & K.O. & F-Değeri \\
\hline A: Çeşit-Genotip & 10 & 620.109 & 62.0109 & $7.80 * * *$ \\
\hline D: Dip / Orta / Uç & 2 & 74.8124 & 10.6875 & 1.34 ö.D. \\
\hline C: Tekerrür & 2 & 9,34767 & 4,67384 & $0,58^{\text {Ö.D. }}$ \\
\hline Hata & 84 & 556.675 & 7.9525 & \\
\hline \multirow[t]{2}{*}{ Toplam } & 98 & 1251.6 & & \\
\hline & \multicolumn{4}{|c|}{ Stoma enlerine ilişkin varyans analizi } \\
\hline Varyasyon Kaynağ1 & S.D. & K.T. & K.O. & F-Değeri \\
\hline A: Çeşit-Genotip & 10 & 394.774 & 39.4774 & $6.34 * * *$ \\
\hline D: Dip / Orta / Uç & 2 & 50.9725 & 7.28179 & $1.17^{\text {Ö.D. }}$ \\
\hline C: Tekerrür & 2 & 12,7981 & 6,39905 & 1,03 ö.D. \\
\hline Hata & 84 & 435.536 & 6.22194 & \\
\hline Toplam & 98 & 881.283 & & \\
\hline
\end{tabular}

***: $(\mathrm{P}<0.001) ;$ *: $(\mathrm{P}<0.05) ; \quad$ ö.D.: Önemli Değil.

Fındık çeşit ve genotipleri açısından yapraklardaki stoma yoğunluğu, stoma genişliği ve stoma uzunluğu üzerine olan etkileri istatistiki olarak oldukça önemli $(\mathrm{P}<0.001)$ bulunmuştur. Yaprak yüzeyinin farklı yerlerinden (dip, orta, uç) örnek almanın stoma yoğunluğu, stoma eni ve stoma boyu üzerine etkisinin istatistiki olarak önemli olmadığı tespit edilmiştir. (Çizelge 1).

Üzerinde çalışlan findık çeşit ve genotiplerinde ortalama stoma sayısı $97.69 \mathrm{~mm}^{2}$ olarak belirlenmiştir. En yüksek stoma sayısı Himdi genotipinde $\left(111.6 \mathrm{~mm}^{2}\right)$ gözlenirken en düşük stoma sayısı Hizan genotipinde $\left(82.8 \mathrm{~mm}^{2}\right)$ tespit edilmiştir. En önemli standart fındık çeşidimiz olan Tombul stoma sayısı $\left(99.00 \mathrm{~mm}^{2}\right)$ açısından tespit edilen ortalama stoma sayısının üzerinde bir değere sahip olmuştur. Stoma boyu 23.31 (Herişte) - 32.03 (Foşa) $\mu \mathrm{m}$ arasında ve stoma eni 19.20 (Cavreş) - 26.78 
(Foşa) $\mu \mathrm{m}$ aralığında saptanmıştır. Stoma uzunluğu ve genişliği açısından Foşa findık çeşidi öne çıkmıştır. İncelenen findık çeşit ve genotiplerinde stoma yapıları Şekil 3'de sunulmuştur.
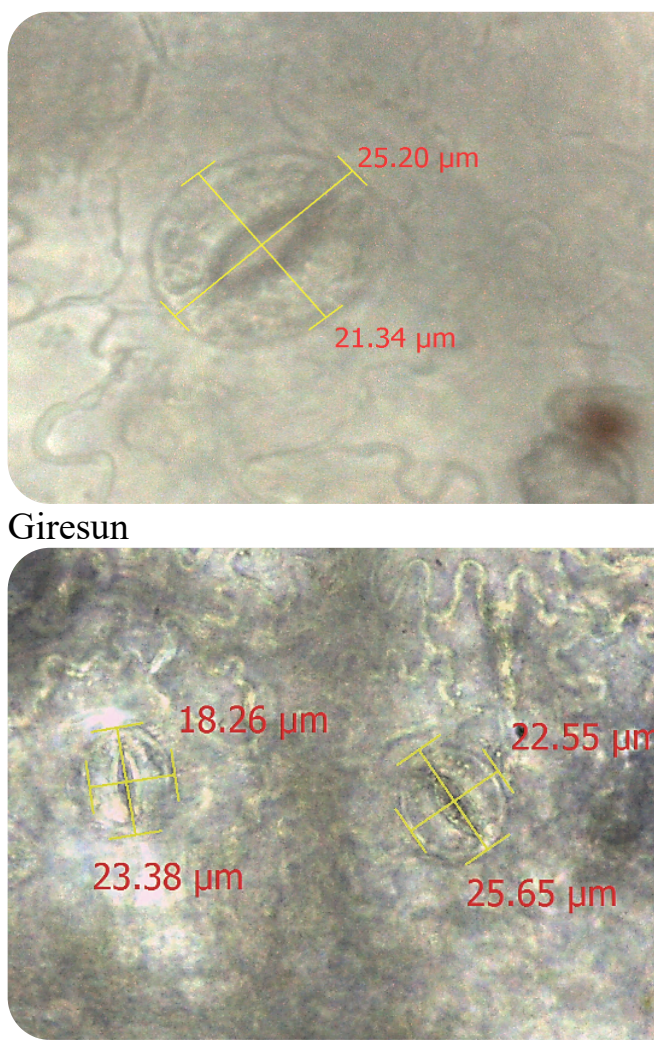

Foşa
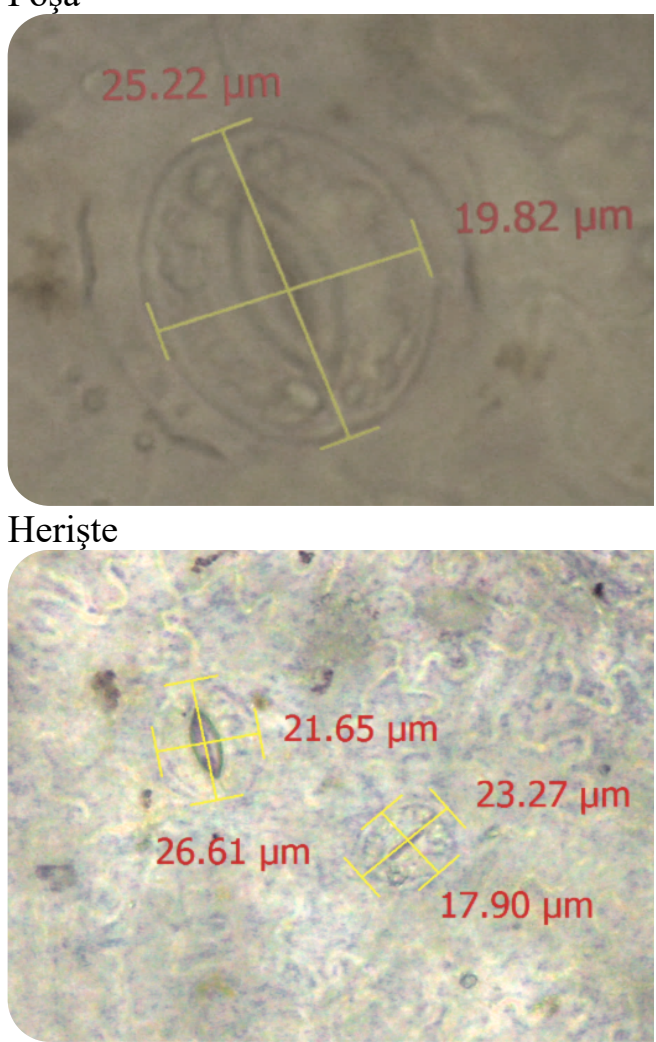

Himdi
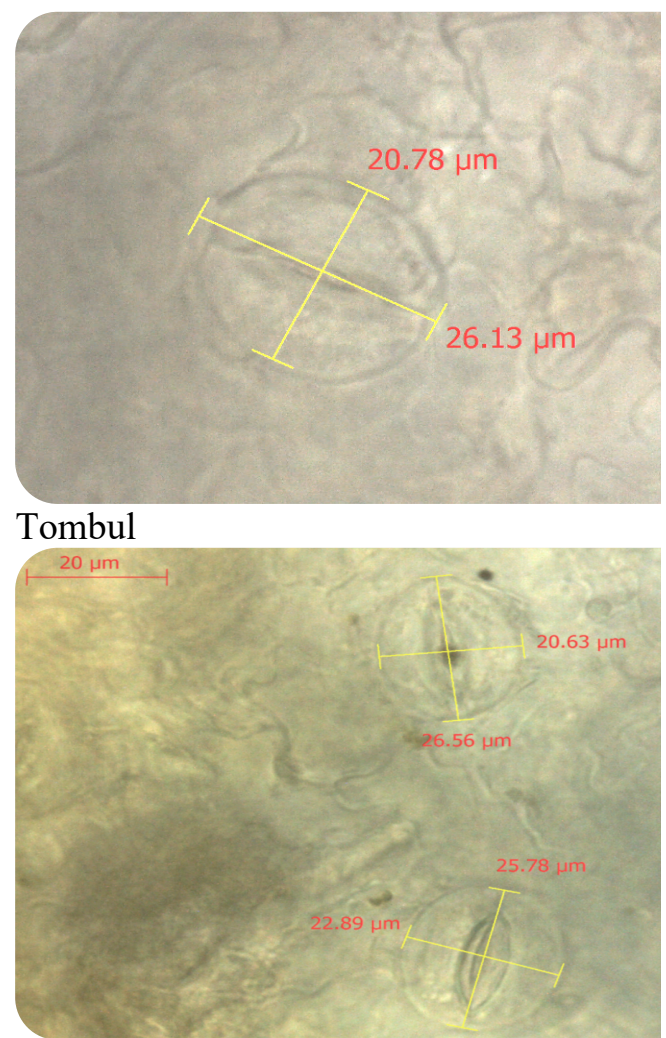

\section{Gevrik}

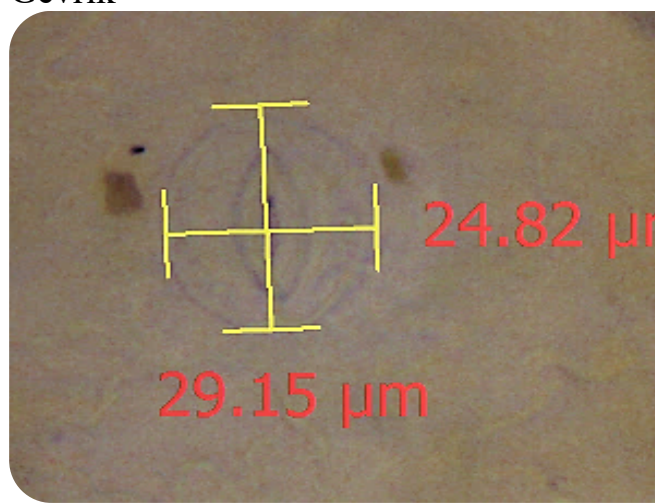

\section{Beynane}

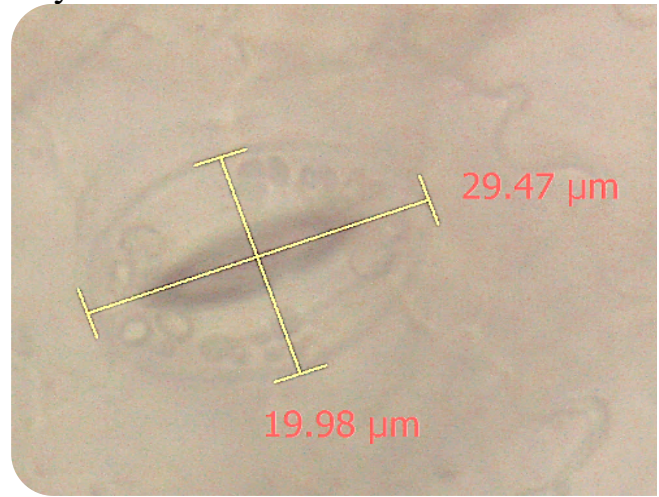

Hizan

Şekil 3. İncelenen findıklardaki stoma görünüşleri. 


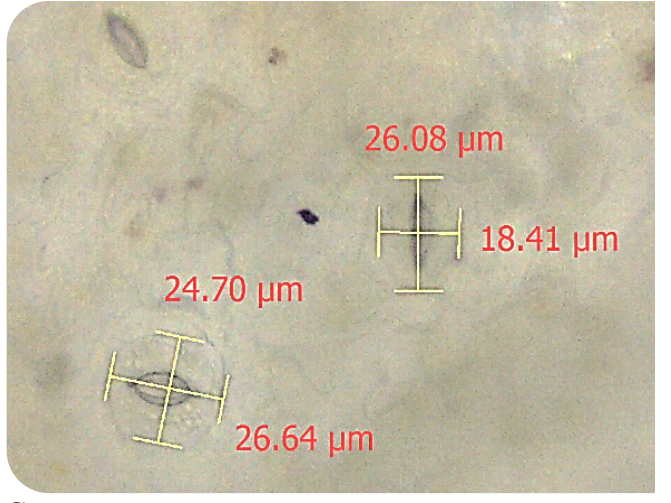

Sevane

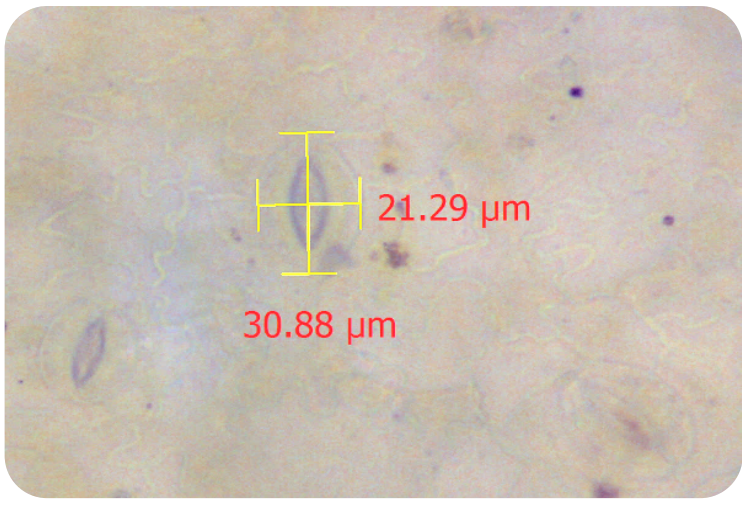

Cavreș

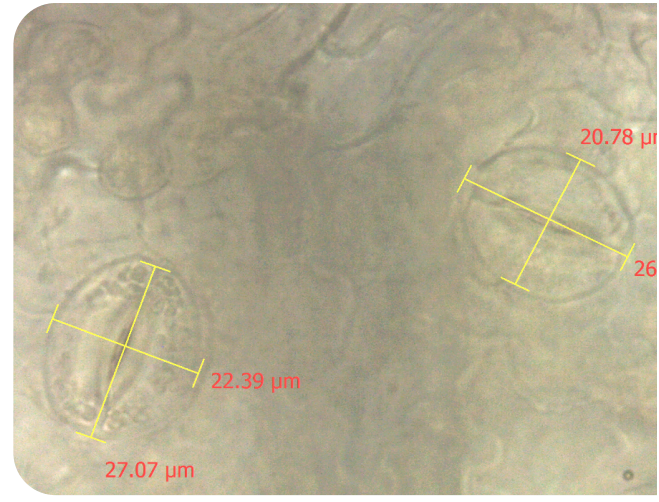

Turşink

Şekil 3. İncelenen findıklardaki stoma görünüşleri (devamı).

Stoma indeksi açısından Himdi (\%19.43) çeşidinde ve Cavreş (\%13.26) genotipinde üst ve alt değerler olarak saptanmıştır. Epidermis hücre sayısı 462.82-612.46 adet $/ \mathrm{mm}^{2}$ arasında değişiklik göstermiştir (Çizelge 2).

Çizelge 2. Fındık çeşit ve genotiplerinde tespit edilen stoma ve epidermal hücre değerleri

\begin{tabular}{|c|c|c|c|c|c|c|c|c|c|c|}
\hline \multirow{2}{*}{$\begin{array}{l}\text { Çeşit/Genotip } \\
\text { Tombul }\end{array}$} & \multicolumn{2}{|c|}{$\begin{array}{c}\text { Stoma Sayıs1 } \\
\left(\mathrm{mm}^{2}\right)\end{array}$} & \multicolumn{2}{|c|}{$\begin{array}{l}\text { Stoma Genişliği } \\
(\mu \mathrm{m})\end{array}$} & \multicolumn{2}{|c|}{$\begin{array}{c}\text { Stoma } \\
\text { Uzunluğu }(\mu \mathrm{m})\end{array}$} & \multicolumn{2}{|c|}{$\begin{array}{c}\text { Stoma İndex } \\
(\%)\end{array}$} & \multicolumn{2}{|c|}{$\begin{array}{l}\text { Epidermal Hücre } \\
\text { say1sı }\left(\mathrm{mm}^{2}\right)\end{array}$} \\
\hline & 99 & $\mathrm{~cd}$ & 23.55 & $\mathrm{~b}$ & 30.41 & $a b$ & 15.44 & cde & 542.24 & $\mathrm{c}$ \\
\hline Foşa & 97.2 & $\mathrm{~d}$ & 26.78 & $\mathrm{a}$ & 32.03 & $\mathrm{a}$ & 17.53 & $\mathrm{~b}$ & 457.12 & $\mathrm{f}$ \\
\hline Giresun & 91.8 & ef & 22.72 & bc & 25.19 & de & 16.29 & bcd & 471.85 & ef \\
\hline Gevrik & 106.2 & $\mathrm{~b}$ & 21.01 & bcde & 25.53 & de & 18.07 & $\mathrm{~b}$ & 481.38 & $\mathrm{e}$ \\
\hline Herişte & 100.8 & $\mathrm{c}$ & 19.43 & de & 23.31 & e & 14.50 & def & 594.35 & $\mathrm{~b}$ \\
\hline Beynane & 104.4 & $\mathrm{~b}$ & 22.08 & bcd & 30.47 & $a b$ & 17.10 & $\mathrm{bc}$ & 506.12 & $\mathrm{~d}$ \\
\hline Himdi & 111.6 & $a$ & 20.41 & cde & 25.39 & de & 19.43 & $\mathrm{a}$ & 462.82 & $\mathrm{f}$ \\
\hline Hizan & 82.8 & g & 23.31 & $b$ & 29.67 & $a b$ & 13.92 & efg & 512.08 & d \\
\hline Cavreş & 93.6 & $\mathrm{e}$ & 19.20 & e & 27.72 & bcd & 13.26 & g & 612.46 & $\mathrm{a}$ \\
\hline Sevane & 97.2 & $\mathrm{~d}$ & 23.81 & $\mathrm{~b}$ & 29.22 & $\mathrm{abc}$ & 13.76 & fg & 609.08 & $\mathrm{a}$ \\
\hline Turşink & 90 & $\mathrm{f}$ & 21.08 & bcde & 26.27 & cde & 14.09 & efg & 548.60 & c \\
\hline Ortalama & 97.69 & & 22.13 & & 27.75 & & 15.76 & & 527.10 & \\
\hline
\end{tabular}

*: Aynı sütunda farklı harflerle gösterilen ortalamalar arasındaki fark önemlidir LSD $(\mathrm{P}<0.05)$.

Avcı ve Aygün, (2014) yapmış oldukları araştırmada, 18 yerli findık çeşidinde stoma özelliklerini belirlemiş̧lerdir. Stomaların hipostomatik olduklarını gözlemişlerdir. Stoma yoğunluğu 83.08 (Kalınkara) - 117.73 (Sivri) adet $/ \mathrm{mm}^{2}$ aralığında değiştiğini rapor etmektedirler. Stoma uzunluğu 22.00-27.45 $\mu \mathrm{m}$ ve stoma genişliği 17.00-22.61 $\mu \mathrm{m}$ aralığında belirlenmiş olup değerler yapmış olduğumuz çalışmayla paralellik arz etmektedir.

Çağlar ve ark., (2004) yapmış oldukları bir çalışmada araştırdıkları cevizdeki stoma yoğunluğunu (Juglans regia L.) $120-217 \mathrm{~mm}^{2}$ arasında değiştiğini rapor etmektedirler. Mert ve ark., 
(2009), elma çeşitlerinde tespit ettikleri stoma sayısının 344.21-619.36 $\mathrm{mm}^{2}$ aralığında olduğunu bildirmektedirler. Antepfistığ 1 çeşitlerinde stoma yoğunluğu üst ve alt yaprak yüzeyinde epidermis 114$151 \mathrm{~mm}^{2}$ ve 171-221 mm² arasında değiştiği rapor edilmektedir (Çağlar ve Tekin, 1999).

Asmalarda stoma yoğunluğu ve boyutlarının gübreleme (Boselli ve Scienza, 1983), fungusit uygulamaları (Sekera, 1983); anaç ve terbiye sistemi (İşçi ve ark., 2015; Atik ve Dardeniz, 2018), çevre koşullarına ve çeşide (Eriş ve Soylu, 1990) göre değiişiklik gösterdiği rapor edilmiştir.

Elde edilen sonuçlara göre fındık çeşit ve genotiplerde stoma sayısının farklılık göstermesi ve bu farklılığın istatistiki açıdan $(\mathrm{P}<0.05)$ önemli olması bitki genetik farklılığının etkisinden kaynaklandığı şekliyle açıklanabilir (Çağlar ve ark., 2004). Genel olarak stoma sayısı türler, çeşitler göre farklılık gösterdiği gibi ekolojik faktörlerin, büyüme koşullarının ve özellikle rakım stoma sayısı üzerine çok önemli bir etkisi bulunmaktadır. Deniz seviyesinden yukarılara çıkıldıkça, rakım arttıkça stomalar artar (Çağlar ve ark., 2004). Benzer şekilde toprakta su eksikliği, bitki besin maddeleri ve 1şık yoğunluğuna dayalı koşullar stoma sayısının artmasına neden olabilir. Çalışmamızda Hizan ilçesinde yetiştirilen findık genotiplerinde belirlenen stoma sayılarının $82.80-111.60 \mathrm{~mm}^{2}$ olarak belirlenmesi rakımdan ziyade stoma dağılımlarındaki farklılığın kuvvetli olarak bir çeşit özelliği olduğunu ortaya koymaktadir.

Farklı iki bölgeden örneklenen findık çeşit ve genotiplerinde stoma sayısı ve genişlikleri arasında anlaml 1 negatif korelasyonlar $(\mathrm{r}=-0.698$ - -0.706) Giresun ve Tombul çeşitlerinden elde edilirken Turşink ve Sevane genotiplerin pozitif korelasyonlar $(\mathrm{r}=0.620-0.856)$ belirlenmiştir tespit edilmiştir (Çizelge 3). Genelde negatif korelasyonlar Trabzon yöresinden örneklenen çeşitlerde bulunurken pozitif korelasyonlar karasal iklimin hüküm sürdüğü 1470 rakımda yetişen genotiplerden elde edilmiştir. Rakım değerleri yüksek olan yörede yetişen fındık genotiplerinde stoma sayısının artması ile birlikte stoma genişliklerinin de artmasına neden olduğu gözlemlenmiştir.

Yaprakları daha büyük stomalar içeren tür ve çeşitler fotosentetik kapasite ve oranın daha yüksek olduğu kaynaklarda rapor edilmektedir (Chandra ve Das, 2000; Çeliktopuz ve ark., 2018). Genel olarak, yapraklardaki stoma yoğunluğu yüksek çeşitlerin stoma genişliklerinin daha dar olduğu bildirilmektedir (Mert ve ark., 2009). Tespit etmiş olduğumuz sonuçlar genel olarak bu ifadeyi destekler niteliktedir.

Stoma yoğunluğu ve stoma genişliklerinin ortalama korelasyon katsayısı $\mathrm{r}=-0.247$ tespit edilirken, stoma yoğunluğu ve stoma uzunluklarının tüm çeşit ve genotiplerin ortalama korelasyon katsayısı $r=-0.380$ olarak belirlenmiştir.

Çizelge 3. Fındık çeşit ve genotiplerinde stoma adedi ile stoma uzunluğu ve stoma genişliği arasındaki korelasyon katsayıları

\begin{tabular}{lcc}
\hline Çeşit/Genotip & Stoma Sayısı-Stoma Genişliği (r) & Stoma Sayıs1-Stoma Uzunluğu (r) \\
\hline Tombul & -0.698 & -0.684 \\
Foşa & 0.154 & -0.004 \\
Giresun & -0.706 & -0.258 \\
\hline Gevrik & 0.391 & 0.358 \\
Herişte & -0.147 & -0.396 \\
Beynane & 0.323 & -0.458 \\
Himdi & -0.077 & -0.170 \\
Hizan & -0.276 & -0.030 \\
Cavreş & 0.428 & 0.120 \\
Sevane & 0.620 & -0.112 \\
Turşink & 0.856 & 0.461 \\
\hline Genel & -0.247 & -0.216 \\
\hline
\end{tabular}

Avcı ve Aygün, (2014) findıkların stoma özellikleri üzerine yapmış oldukları çalışmada stoma sayısı ile stoma boyu arasında (-0.407) ve stoma sayısı ile stoma eni arasinda $(-0.380)$ negatif korelasyon belirlenmişlerdir. İnceledikleri çeşitlerin korelasyon katsayıları -0.451 (Kan) ile 0.192 (Uzunmusa) aralığında değişim göstermiş olup yapmış olduğumuz çalışmayla benzer niteliktedir. Stoma yoğunluğu ile stoma büyüklüğü arasında ceviz ve elmada negatif korelasyon olduğu farklı araştırıcılar tarafından bildirilmektedir (Çağlar ve ark., 2004; Mert ve ark., 2009). Elma çeşitlerinde stoma yoğunluğu ve büyüklükleri arasındaki korelasyon katsayıları Vista Bella'da r=-0.805, Fuji'de $r=-0.860$; Granny 
Smith'de r=-0.205 ve Mondial'de r=0.659 rapor edilmektedir (Mert ve ark., 2009). Görüldüğü üzere farklı elma çeşitlerinde stoma yoğunluğu ve büyüklükleri hem negatif hem de pozitif korelasyonun bulunduğu bildirilmiş olup çalışmamızda da benzer durum Çizelge 3'de gözlenmektedir.

\section{Sonuç}

$\mathrm{Bu}$ çalışma neticesinde stomanın findık çeşit ve genotiplerinin yapraklarının alt yüzeyinde bulunduğu (hipostamik) belirlenmiştir. Üzerinde çalışılan 11 farklı findık çeşit ve genotipinde stoma sayıları açısından istatistiki anlamda farklılık belirlenmiştir. Fındıklarda stoma üzerine Avcı ve Aygün, (2014) çalışması dışında şu ana kadar yapılan çalışmalarda stoma özelliklerinin fotosentez, bitki gelişimi ve verimi bitki su ilişkileri üzerine etkisi hakkında herhangi bir çalışmaya rastlanılmamıştır.

Çalışmada çeşit ve genotipin stoma yoğunluğu üzerine olan etkisinin önemli olduğu ancak yaprak yüzeyinin farklı yerlerinden örnek almanın stoma yoğunluğu üzerine etkisinin önemsiz olduğu tespit edilmiştir. Aynı şekilde, çeşit ve genotipin stoma boyutları üzerine olan etkilerinin önemli olduğu ancak yaprağın alınma yerinin ve yaprak yüzeyinin farklı yerlerinden örnek almanın stoma boyutları üzerine olan etkisinin önemsiz olduğu belirlenmiştir. Stoma yoğunluğu açısından çeşit ve genotipler arasındaki farklılığın önemli bulunması, stoma yoğunluğunun findık çeşit ve genotiplerine özgü olduğunu ortaya koymaktadır.

Fındık yapraklarında stomaların bir kısmı yaprak mezofil dokusunun mantar tabakası içinde gömülmüş olarak bulunması, yaprak tüylülüğünün çok fazla olması, yaprakların gevrek yapıda olması, yaprak yüzeyinin pürüzlü ve dalgalı olması nedeniyle findık yapraklarında daha iyi bir stomatal gözlemlemenin yapılmasında saydamlaştırma yönteminin kullanılabilir olduğu gözlenmiştir.

Elde edilen bulgulara dayanarak, saydamlaştırma yönteminde yaprakların tam olarak saydamlaşmasının 24-36 saat aldığı, kullanılacak olan piyasada satılan hipoların \%17-20 saflıkta bulunduğu unutulmamalıdır. Kaliteli hipo markaların tercih edilmesi ile daha net ve şeffaf saydamlaşmış yüzey elde edilebildiği saptanmıştır.

\section{Teșekkür}

Bu çalışma Van Yüzüncü Yı1 Üniversitesi Bilimsel araştırma Projeleri Başkanlığı tarafından FBA-2019-8449 nolu proje olarak desteklenmiştir. Çalışmanın yürütülmesinde katkılarından dolayı BAP birimine teşekkür ederiz.

\section{Kaynakça}

Aras, S., \& Eşitken, A. (2019). Responses of apple plants to salinity stress. Yüzüncü Yll Üniversitesi Tarım Bilimleri Dergisi, 29(2), 253-257 . DOI: 10.29133/yyutbd.494677.

Atik, F., \& Dardeniz, A. (2018). Yalova İncisi üzüm çeşidinde farklı taç yönetimi uygulamalarının yaprakların stoma özellikleri üzerine etkileri. ÇOMÜ, Ziraat Fakültesi Der, 6(özel sayı), 33-37.

Avci, N., \& Aygün, A. (2014). Determination of stomatal density and distribution on leaves of Turkish hazelnut (Corylus avellana L.) cultivars. Tarm Bilimleri Dergisi J. of Agricultural Sciences, 20, 454-459.

Bierhuizen, J. F., Bierhuizen, J. M. \& Martakis, G. F. P. (1984). The effect of light and $\mathrm{CO}_{2}$ on photosynthesis of various pot plants. Gartenbauwissenschaft, 49(5-6), 251-257.

Boselli, M., \& Scienza, A. (1983). Effects of potassium fertilization on density and morphological characteristics of stomata in grapevines. Vignevini (Bologna), 10(1-2), 27-32.

Brownlee, C. (2001). The long and short of stomatal density signals. Trends in Plant Science, 6, 41-442.

Çağlar, S., \& Tekin, H. (1999). Farklı Pistacia anaçlarına aşılı antepfıstığı çeşitlerinin stoma yoğunlukları. Turkish Journal of Agriculture and Forestry, 23(5), 1029-1032.

Çağlar, S., Sütyemez, M., \& Bayazıt, S. (2004). Seçilmiş bazı ceviz (Juglans Regia) tiplerinin stoma yoğunlukları. Akdeniz Üniversitesi Ziraat Fakültesi Dergisi, 17(2), 169-174.

Çeliktopuz, E., Kapur, B., Sarıdaş, M., \& Paydaş Kargı, S. (2018). Determining the yield and morphophysiological responses of 'fortuna' strawberry cv. of using different irrigation levels with biostimulant application. Yüzüncü Yll Üniversitesi Tarım Bilimleri Dergisi, 28(4), 368-374. DOI: $10.29133 /$ yyutbd.426079. 
Chandra, K., \& Das, A., K. (2000). Correlation and interaction of physiological parameters in rice under rainfed transplanted condition. Journal of Research Assam Agriculture University, 19, 251-254.

Durmaz, N.E., (2014). Asma yapraklarında stoma yoğunluğunun saptanmasında saydamlaştırma ve kalıp alma yöntemlerinin karşılaştırılması. (Yüksek Lisans Tezi, basılmamış). Namık Kemal Üniversitesi Fen Bilimleri Enstitüsü Bahçe Bitkileri Anabilim Dal, Tekirdağ.

Düzenli, S., \& Ergenoğlu, F. (1991). Yüksek terbiye sisteminde değişik şekiller verilmiş ve farklı anaçlar üzerine aşılı bazı Vitis vinifera çeşitlerinde stoma yoğunluklarının araştırılması. Doğa - J. of Agriculture and Forestry, 15, 308-317.

Eriş, A., \& Soylu, A. (1990). Stomatal density in various Turkish grape cultivars. Vitis Special Issue, 382-389.

İşçi, B., Altındişli, A., \& Kaçar, E. (2015). Farklı anaçlar üzerine aşılı farklı üzüm çeşitlerinde stoma dağılımı üzerine araştırmalar. ÇOMÜ, Ziraat Fakültesi Dergisi, 3(1), 35-39.

Küçükyumuk, C., Sarısu, H., Yıldız, H., Kaçal, E., \& Koçal, H. (2015). Farklı anaçlar üzerine aş11ı 0900 ziraat kiraz çeşidinde su stresinin bazı vejetatif gelişim parametrelerine etkisi. Yüzüncü Yll Üniversitesi Tartm Bilimleri Dergisi, 25(2), 180-192 . DOI: 10.29133/yyutbd.236404.

Meidner, H., \& Mansfield, T. A. (1969). Physiology of stomata. Mc Graw-Hill, Newyork, USA

Mert, C., Barut, E., \& Uysal, T. (2009). Farklı anaçlar üzerine aş11 elma çeşitlerinin stoma morfolojilerinin araştırılması. Tarım Bilimleri Araştırma Dergisi, 2(2), 61-64.

Şahin, T., \& Soylu, A. (1991). Seleksiyonla Elde Edilmiş Bazı Kestane Çeşitlerinin Yaprak Morfolojileri ve Stoma Dağıllmları Üzerinde Araştırmalar. Uludağ Üniversitesi Fen Bilimleri Enstitüsü Bilimsel Raporlar serisi:10, $20 \mathrm{~s}$.

Sarwar, A. K. M., Golam Abdul Karim, A., \& Masud Rana, S. M. A. (2013). Influence of stomatal characteristics on yield and yield attributes of rice. Journal of Bangladesh Agricultural University, 11(1), 47-52.

Sekera, D., (1983). The effect of fungicides and fungicide combinations on grape leaf stomata size and aperture. Vinohrad (Bratislava), 21, 29-31.

Sophie, Y. D., Marron, N., Barbra, K., \& Reinhart, C. (2008). Genetic variation of stomatal traits and carbon 1sotope discrimination in two hybrid poplar families (Populus deltoides 'S9-2' x P. nigra 'Ghoy' and P. deltoides 'S9-2' x P. trichocarpa 'V24'). Annals of Botany, 102, 399-407.

Yentür, S. (1984). Bitki Anatomisi. İstanbul Üniversitesi Fen Fakültesi Yayınları İstanbul, No:191. 